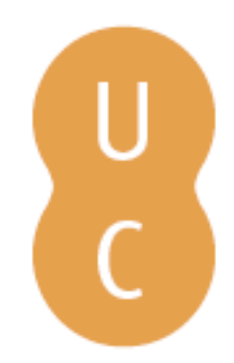

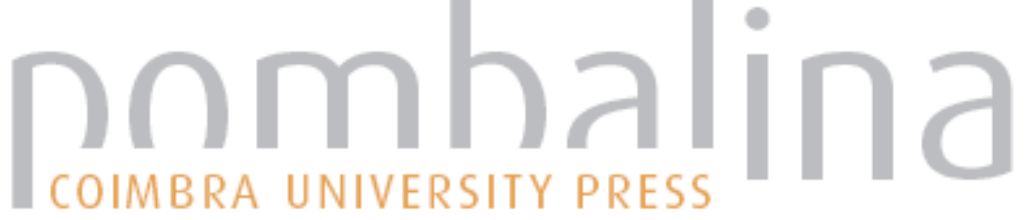

\section{Proteomic investigation of tissues of medical interest by MALDI MSI}

\begin{tabular}{|c|c|}
\hline Autor(es): & $\begin{array}{l}\text { Djidja, M. C.; Clench, M. R.; Loadman, P. M.; Sutton, C. W.; Scriven, P. P. } \\
\text { Claude, E.; Snel, M. F.; Franck, J.; Salzet, M.; Burrell, M.; Francese, S. }\end{array}$ \\
\hline Publicado por: & $\begin{array}{l}\text { Imprensa da Universidade de Coimbra; International Academy of Legal } \\
\text { Medicine }\end{array}$ \\
\hline $\begin{array}{l}\text { URL } \\
\text { persistente: }\end{array}$ & URI:http://hdl.handle.net/10316.2/31858 \\
\hline DOI: & DOI:http://dx.doi.org/10.14195/978-989-26-0173-1_57 \\
\hline Accessed: & 26-Apr-2023 14:13:24 \\
\hline
\end{tabular}

A navegação consulta e descarregamento dos títulos inseridos nas Bibliotecas Digitais UC Digitalis, UC Pombalina e UC Impactum, pressupõem a aceitação plena e sem reservas dos Termos e Condições de Uso destas Bibliotecas Digitais, disponíveis em https://digitalis.uc.pt/pt-pt/termos.

Conforme exposto nos referidos Termos e Condições de Uso, o descarregamento de títulos de acesso restrito requer uma licença válida de autorização devendo o utilizador aceder ao(s) documento(s) a partir de um endereço de IP da instituição detentora da supramencionada licença.

Ao utilizador é apenas permitido o descarregamento para uso pessoal, pelo que o emprego do(s) título(s) descarregado(s) para outro fim, designadamente comercial, carece de autorização do respetivo autor ou editor da obra.

Na medida em que todas as obras da UC Digitalis se encontram protegidas pelo Código do Direito de Autor e Direitos Conexos e demais legislação aplicável, toda a cópia, parcial ou total, deste documento, nos casos em que é legalmente admitida, deverá conter ou fazer-se acompanhar por este aviso.

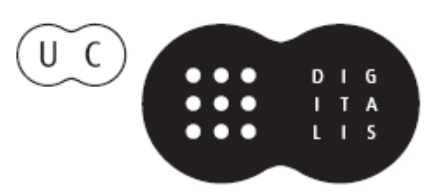




\section{Duarte Nuno Vieira Anthony Busuttil \\ Denis Cusack • Philip Beth}
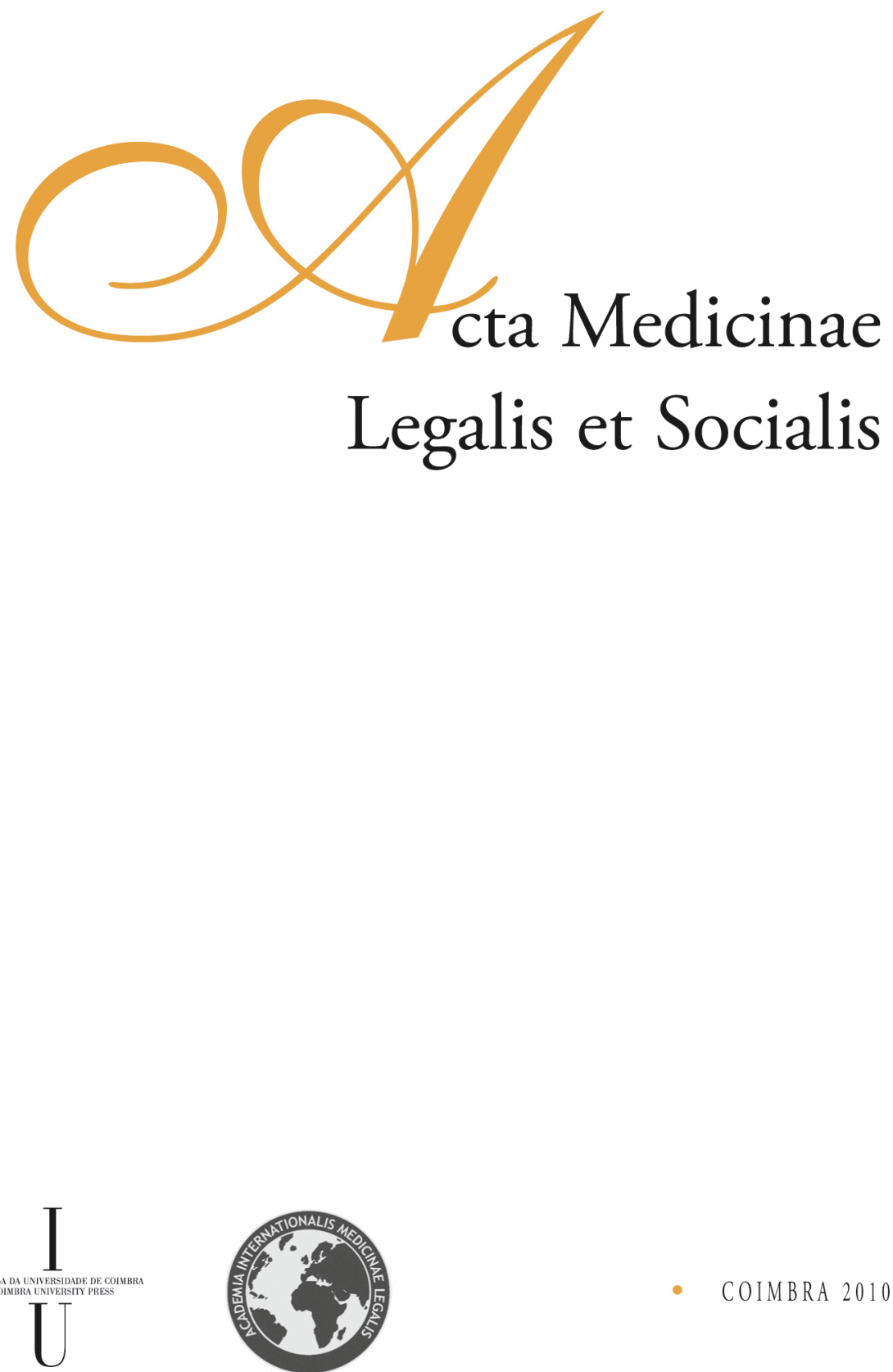
M. C. Djidja ${ }^{1}$, M. R. Clench ${ }^{1}$, P. M. Loadman ${ }^{2}$, C. W. Sutton ${ }^{2}$, P. Scriven ${ }^{3}$, E. Claude ${ }^{4}$, M. F. Snel ${ }^{4}$, J. Franck ${ }^{5}$, M. Salzet ${ }^{5}$, M. Burrell ${ }^{6}$, S. Francese ${ }^{1}$

${ }^{1}$ Sheffield Hallam University, Sheffield, UK

2 Institute of Cancer Therapeutics, University of Bradford, UK

${ }^{3}$ Academic Surgical Oncology Unit, University of Sheffield, UK

${ }^{4}$ Waters Corporation, Manchester, UK

${ }^{5}$ Laboratoire de Neuroimmunologie des Annèlides, University of Science and Technologies of Lille, Villeneuve d'Ascq, France

${ }^{6}$ University of Sheffield, $U K$

\title{
PROTEOMIC INVESTIGATION OF TISSUES OF MEDICAL INTEREST BY MALDI MSI
}

\begin{abstract}
MALDI Mass Spectrometry Imaging (MALDI MSI) enables images of the distribution of endogenous/xenobiotic compounds to be obtained directly from intact tissue sections. The ability to localise thousand of ions in a single analysis, without using radioactive probes or antibodies, makes it a very powerful tool in biomarker discovery. Technological improvements of in situ proteomic protocols have recently enabled MALDI MSI to be used for the identification of up/down regulated species in both snap frozen and archived tissues such as formalin fixed paraffin embedded (FFPE) samples. A further improvement of these protocols, the incorporation of a surfactant in the enzymatic digestion step, is discussed for the investigation of protein distribution and expression from frozen and FFPE adenocarcinoma tissue sections.
\end{abstract}

\section{Introduction}

MALDI Mass Spectrometry Imaging (MALDI MSI) is an advanced MS technique first reported by Richard Caprioli in 1997 [1]. This technology enables the visualization of the spatial distribution of endogenous and xenobiotic compounds directly from intact tissue sections. A variety of molecules can be investigated ranging from drugs, lipids and peptides to proteins. Typically, in a direct MALDI MSI approach, snap frozen tissues are mounted and sectioned in a cryostat at a thickness varying between 10 and $20 \mu \mathrm{m}$. The section is then either spotted or sprayed with an UV absorbing matrix. In MALDI Imaging mode, the laser (UV or solid state) is automatically fired on a raster of points over the section. Each ion within the mass spectra acquired can be visualised as a two-dimensional image by using its $\mathrm{m} / \mathrm{z}$ ratio (Fig. 1 ). The closer the raster points, the higher the image resolution. This technology can operate in both Imaging and Profiling mode and the choice depends on the goal to be achieved. In Imaging mode, high resolution images of the ion distribution are desired and consequently the matrix is applied by homogeneously spray coating the section. In profiling mode, rather then images, the aim is to obtain and compare molecular profiles (as mass spectra) in specific tissue regions. This is accomplished by depositing discrete spots of matrix on the regions of interest and recording mass spectra from each spot separately. This is very quick and helpful when differential proteomics studies are undertaken on tissues of medical 
interest. In a biomarker discovery experiment therefore, instead of tedious extraction methods, pre-purification and separation through 2D electrophoresis or bidimensional HPLC followed by MS, this technology gives ready access to an enormous amount of information and, at the same time, retains the spatial information [2].

In 2004 Chaurand and co-workers reported one of the first demonstrations of the potential of MALDI-MSI in medicine [3]. In an attempt to demonstrate the feasibility of the technology as a diagnostic and prognostic tool for assessment of cancer staging, they were able to distinguish between gliomas and non-tumor brain tissue as well as to sub-classify grade IV gliomas from grades II and III at a molecular level, by observing in the spectra profiles an up-regulation of the protein $S-100 \beta$ in the high versus low grade tumours. This was confirmed by the mass images of distribution of the protein and validated by immunohistochemistry. These results suggested an important role for MALDI MSI which could in fact be crucial in those borderline cases where the diagnosis relies uniquely on the personal judgment and experience of the histopathologist. Moreover, simultaneous immunochemical localization of proteins/peptides in one experiment generally provides information on two to three markers at the same time, thus suggesting that immunohistochemistry is more amenable for biomarker validation rather then for biomarker discovery.

A major source of tissue samples are potentially the formalin-fixed, paraffin-embedded (FFPE) tissues found in hospital libraries. However, because of the predictable ion suppression events, MALDI MSI was initially thought only to be applicable to frozen tissues. This prevented access to huge tissue archives and information from tissues which are already analysed and diagnosed. Indeed, for FFPE tissues, the older they get, the more intricate protein network the formalin promotes, thus significantly lowering signal intensity and resolution. Nonetheless in 2007, Lemaire and collaborators developed a protocol showing feasibility of MALDI MSI for the investigation of FFPE tissues [4]. The authors demonstrated that for less than 1 year old FFPE tissues, the use of 2,4 DNPH as matrix, which blocks unreacted formalin, combined with on tissue digestion, for up to less than 2 years old FFPE tissues, followed by MS and MS/MS analysis, is a valid experimental approach to access archived tissues. Proteomic investigation by in situ tryptic digestion was first introduced by the group of M. Setou [5] and it is now a rather consolidated methodology but it had never be applied to FFPE tissues before the work of Lemaire and colleagues. Despite this revolutionary approach, sensitivity can still be an issue, especially for older FFPE tissues. Here, taking stock from all the previous work, a four step methodology is suggested to improve proteomic investigation of both frozen and FFPE tissues. This study has been recently published [6] and used, as models, xenograft breast tumours and FFPE breast tumour sections. The major novel elements were the inclusion of a non ionic detergent (octylglucoside, OcGlu) for a more efficient in situ proteolysis, and the use of Ion Mobility Mass Spectrometry (IMS) to retrieve MS/MS spectra of isobaric ions, thus improving protein identification. This articles focuses on these two aspects of the experimental procedure.

\section{Materials and Methods}

Modified sequence-grade trypsin was purchased from Promega (Southampton, UK). All other materials were purchased from Sigma-Aldrich (Dorset, UK). MCF7 
breast tumour xenografts were obtained from the Institute of Cancer Therapeutics, Bradford, UK. Ex vivo human breast tumour tissue samples were obtained following fully informed patient consent and local ethical committee approval.

\subsection{Tissue preparation}

Frozen MCF7 xenograft tissue samples were cut in a cryostat operating at $-20^{\circ} \mathrm{C}$. Five $10 \mu \mathrm{m}$ sections were obtained and thaw-mounted onto either an aluminum foil, or an ITO glass slide. Rinsing procedures, involving washings in ethanol at different percentages and in chloroform, were performed to increase the MS data quality as described elsewhere [7]. Sections were then submitted to enzymatic digestion and matrix deposition. For FFPE tissue sections, paraffin wax was first removed according to procedures described previously [8].

\subsection{In situ digestion}

In situ digestion was performed using a $0.05 \mathrm{mg} / \mathrm{mL}$ trypsin acqueus solution containing $0.1 \%$ of OcGlc. $100-150 \mathrm{~nL}$ of trypsin solution were deposited on the section using a Sun-Collect MALDI-Spotter (SunChrom). The spot-to-spot distance was set at $400 \mu \mathrm{m}$. The section was then incubated for $2 \mathrm{~h}$ in a humid chamber at $37^{\circ} \mathrm{C}$. Following enzymatic digestion, matrix deposition was performed using a robotic printer. An ionic matrix, consisting of CHCA mixed with ANI (CHCA/ANI), was used for MALDI MS analysis of the resulting peptides.

\subsection{In situ peptide analysis by MALDI-MSI and direct protein identification with IMS MALDI-MS/MS}

MALDI-MSI data were acquired in the reflector and positive mode using either a MALDI SYNAPT ${ }^{\mathrm{TM}} \mathrm{HDMS}$ system (Waters Corporation, Milford, MA) operating with a $200 \mathrm{~Hz}$ Nd:Yag laser, or an Ultraflex ${ }^{\mathrm{TM}}$ II MALDI-TOF/TOF instrument (Bruker Daltoniks, Bremen, Germany) equipped with a Smartbeam ${ }^{\mathrm{TM}}$ laser. Standards for spectral calibration consisted of poly(ethylene glycol) ranging between $\mathrm{m} / \mathrm{z} 400$ and $3000 \mathrm{Da}$ and a peptide mixture ranging between 900 and 3500 Da. Full scan mass spectra were recorded from 600 up to $5000 \mathrm{Da}$. Images were generated and reconstructed using Biomap 3.7.5 and FlexImaging ${ }^{\text {TM }} 2.0$ software. MALDI MS/MS analyses were acquired using the MALDI SYNAPT ${ }^{\mathrm{TM}}$ HDMS operating in IMS mode directly from the digested tumour tissue sections. MS/MS spectra were submitted to a MASCOT query search and searched against the Swiss-Prot database. De novo sequencing was performed manually and using the PepSeq ${ }^{\mathrm{TM}}$ de novo interactive MS/MS sequencing tool.

\section{Results}

\subsection{In situ protein identification by MALDI-MSI}

In order to improve the detection of low abundant and high mass proteins, a main experimental step was introduced consisting in the use of a non ionic detergent such 
as OcGlu in the trypsin solution. This proved to be a crucial step to improve peptide yield. Fig. 2 shows a comparison of spectra profiles obtained after in situ digestion performed with trypsin in either water (Fig. 2A) or in a solution containing $0.1 \%$ of the detergent at $37^{\circ} \mathrm{C}$ for $2 \mathrm{~h}$ (Fig. $2 \mathrm{~B}$ ). It is clear that in the latter case, many more peptide signals were generated. These were later identified and attributed to low abundant proteins. Histones and stress proteins such as Grp75 were identified through MS/MS analysis and confirmed by direct protein analysis (profiling and imaging) [6]. The same methodology was applied to FFPE breast tumour sections with equally successful results.

\subsection{Ion Mobility Mass Spectrometry}

In order to address ion signal overlap from isobaric peptides generated by the use of OcGlu, IMS was used as a mass separation step prior peptide fragmentation. Figure 3A shows the IMS of two isobaric species of $\mathrm{m} / \mathrm{z} 850$ arising from the direct MS/MS analysis. When a MASCOT search was performed on the entire MS/MS spectrum, without taking into account the mobility separation, no significant protein identification was obtained. However the IMS data can be processed thus extracting individual MS/MS spectra corresponding to each species (Fig 3B and 3C). In this way the species at $\mathrm{m} / \mathrm{z} 850.47$ could be fragmented and the fragments imported into MASCOT allowing the identification of the histone H2A. Localisation of this protein in the tumour areas was successful for both frozen and FFPE tumour sections (Fig. 4a).

\section{Discussion}

An improved methodology for in situ proteomic investigation of tissues of medical interest (both frozen and FFPE), is reported. In particular, the inclusion of OcGlu as a non ionic detergent in the proteolytic step has shown to increase the number of signals detected relating to low abundant proteins. To overcome the overlap of peptide signals deriving from the improved proteolysis, one approach is to use a high resolving power mass spectrometer allowing accurate mass detection. In the present work a MALDI instrument has been used allowing IMS, thus enabling separation of isobaric peptides on the basis of their collisional cross section. This opportunity allows the obtainment of two separate MS/MS spectra for the isobaric species and has been found to improve the selectivity and facilitate database search, as shown for the species at $\mathrm{m} / \mathrm{z} 850$. Numerous protein signals were detected and some proteins including histone $\mathrm{H} 3, \mathrm{H} 4$ and Grp75 present in the tumour region were identified [6].

A more detailed and comprehensive MALDI based proteomic workflow for improved proteomic investigation and validation of biomarkers in tissues of medical interest is shown in Fig 5. Briefly, this strategy ideally includes the use of high resolving mass spectrometry as well as the use of IMS to potentiate protein detection, profiling, imaging and identification. A parallel analysis by microextraction, digestion and nanoLC MS MS analysis could be simultaneously performed. The peptide maps generated are submitted to database search for protein ID supported by their fragmentation spectra, imaged 
and submitted to statistical analysis to pinpoint biomarkers. Immunohistochemistry is used as last methodological step for biomarker validation.

\section{Conclusions}

The present work demonstrates that the incorporation of a non ionic detergent in the proteolytic solution, combined with the use of IMS greatly improves protein identification in both frozen and FFPE tissues.

The recent past, the present work and further improvement in the development of a more and more efficient MALDI MS based proteomic methodology, leave little doubt about the role and the potential of this technology for the diagnosis of medical conditions at an early stage as well as prognosis of the treatment.

\section{References}

1. CAPRIOLI R.M., FARMER T.B., GILE, J., Molecular Imaging of Biological Samples: Localization of Peptides and Proteins Using MALDI-TOF MS; Anal Chem, 69, 47514760, 1997.

2. FRANCESE S., DANI FR., TRALDI P., et al., MALDI Mass Spectrometry Imaging, from its origin up to today: the state of the art; Comb Chem High Throughput Screen 12, 156-74 (2009).

3. CHAURAND P., SANDERS M.E., JENSEN R.A., CAPRIOLI R.M., Proteomics in diagnostic pathology: profiling and imaging proteins directly in tissue sections, Am J Pathol, 165, 1057-1068, 2004.

4. LEMAIRE R., DESMONS A., TABET J.C. et al., Direct Analysis and MALDI Imaging of Formalin-Fixed, Paraffin-Embedded Tissue Sections; J Prot Res, 6, 1295-1305, 2007.

5. SHIMMA S., FURUTA M., ICHIMURA K. et al., A novel approach to in situ proteome analysis using chemical inkjet printing technology and MALDI-QIT-TOF tandem mass spectrometer; J Mass Spectrom Soc Jap, 54, 133-140, 2006.

6. DJIDJA M-C., FRANCESE S., LOADMAN P.M. et al., Detergent addition to tryptic digests and ion mobility separation prior to MS/MS improves peptide yield and protein identification for in situ proteomic investigation of frozen and formalin-fixed paraffinembedded adenocarcinoma tissue sections; Proteomics, 9, 1-15, 2009.

7. LEMAIRE R., WISZTORSKI M., DESMONS A., et al., MALDI-MS direct tissue analysis of proteins: improving signal sensitivity using organic treatments. Anal Chem, 78, 7145-7153, 2006.

8. HOOD B. L., DARFLER M. M., GUIEL T. G., et al., Proteomic analysis of formalin-fixed prostate cancer tissue. Mol. Cell. Proteomics, 4, 1741-1753, 2005. 


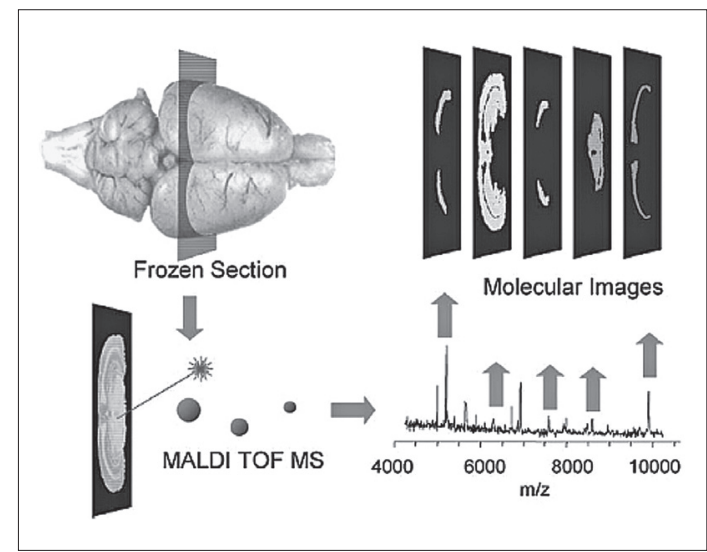

Figure 1 - Schematics of MALDI MSI from sample preparation to data analysis ${ }^{1}$.

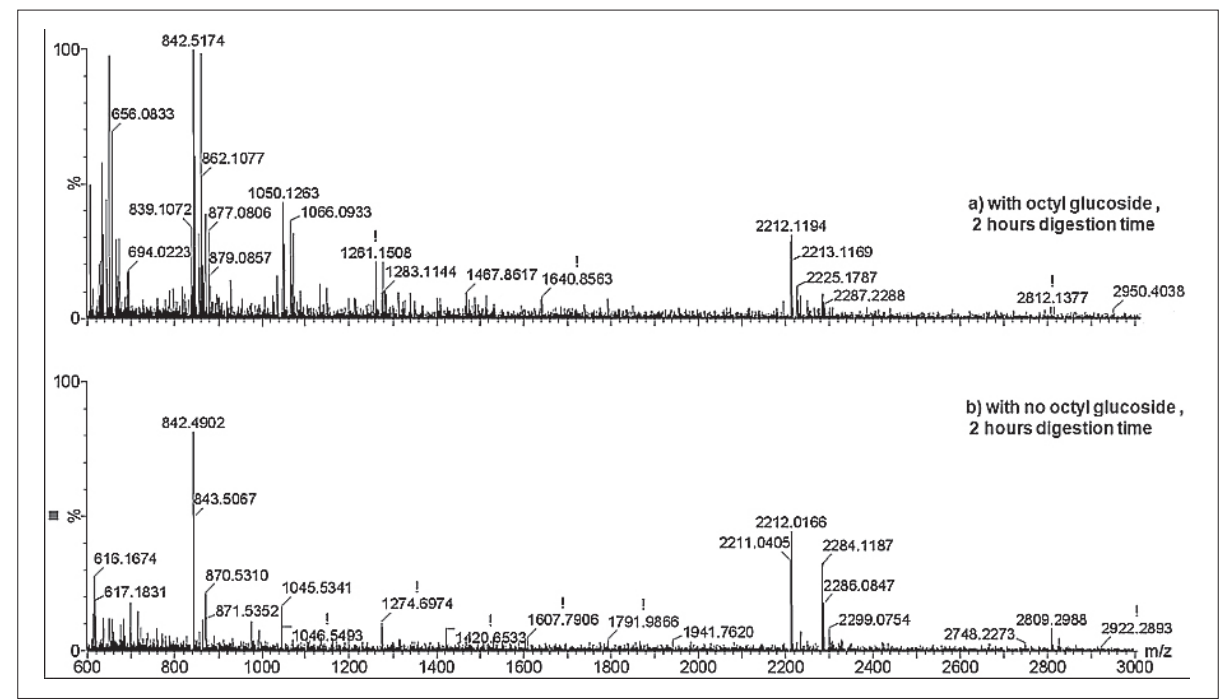

Figure 2 - Improved in situ tissue digestion. Panel A displays the observed peptide profiles obtained using trypsin in water compared to the one generated by a trypsin solution containing $0.1 \%$ of OcGlc (Panel B) ${ }^{2}$.

${ }^{1}$ Reprinted from Stoeckli, M.; Staab, D.; Staufenbiel, M.; Wiederhold, K.H. Molecular imaging of amyloid $B$ peptides in mouse brain sections using mass spectrometry. Anal. Biochem., 2002, 311, 33-39, with permission from Elsevier.

${ }^{2}$ Reproduced and adapted by permission of John Wiley \& Sons from Djidja et al, Proteomics, 9, $1-15$ (2009). 


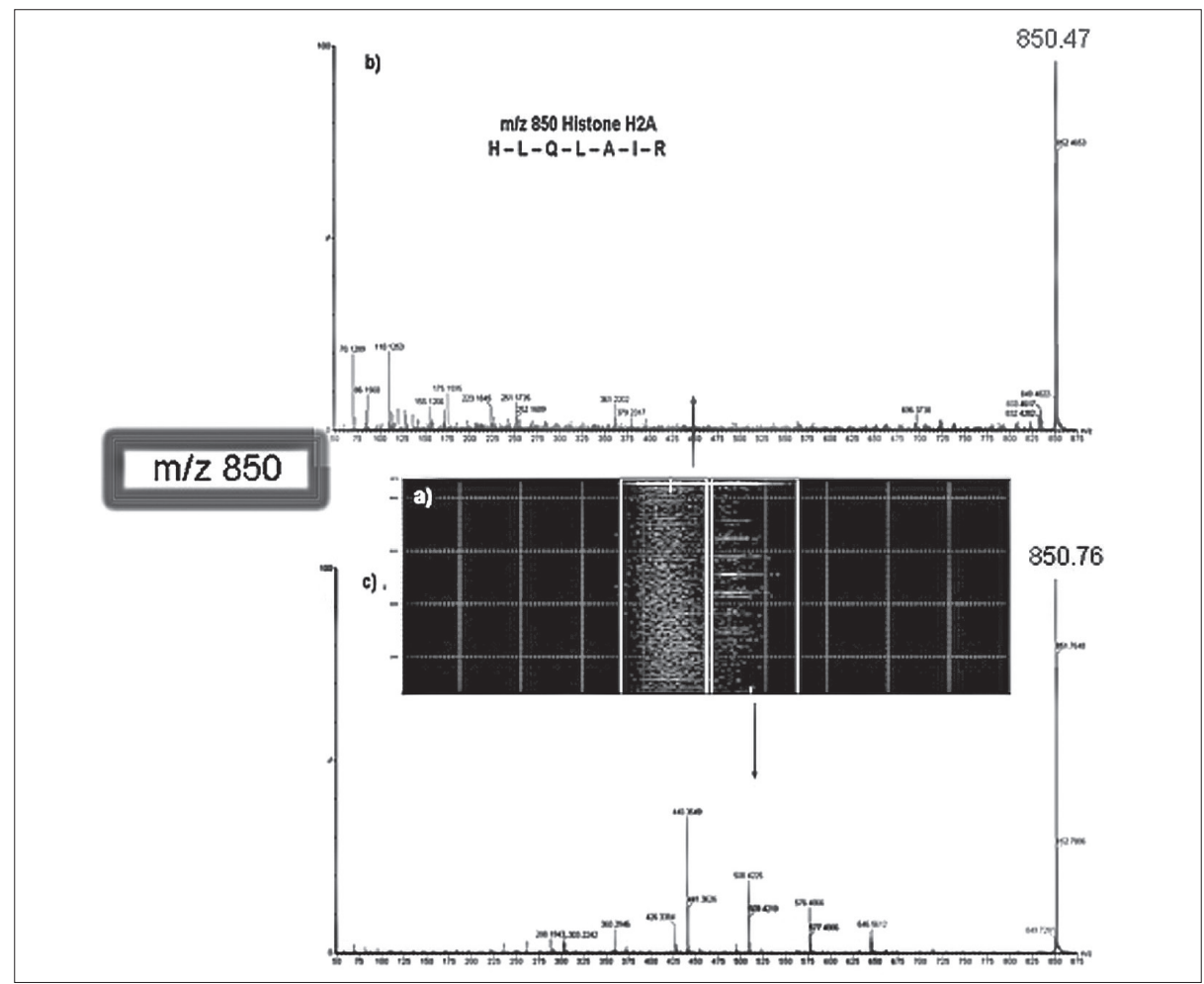

Figure 3 - IMS of the ion signal at $\mathrm{m} / \mathrm{z} 850$. The observed "Driftscope" plot (A) displays interference between species in MS/MS analysis mode. These species can be separated using their mobility. Different MS/MS spectra (B and C) can be extracted using the IMS. ${ }^{2}$

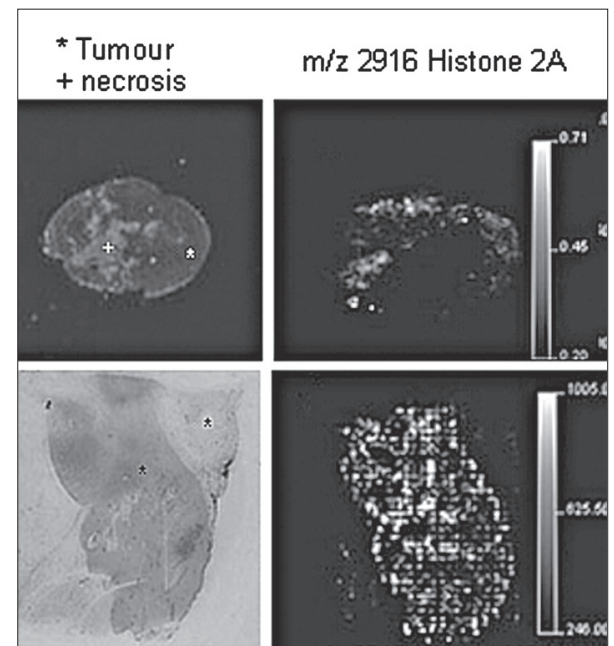

Figure 4 - Localisation maps of histone H2A. The protein was identified and localised in the tumour region through the peptide at $\mathrm{m} / \mathrm{z} 2916$ in frozen and FFPE sections. ${ }^{2}$

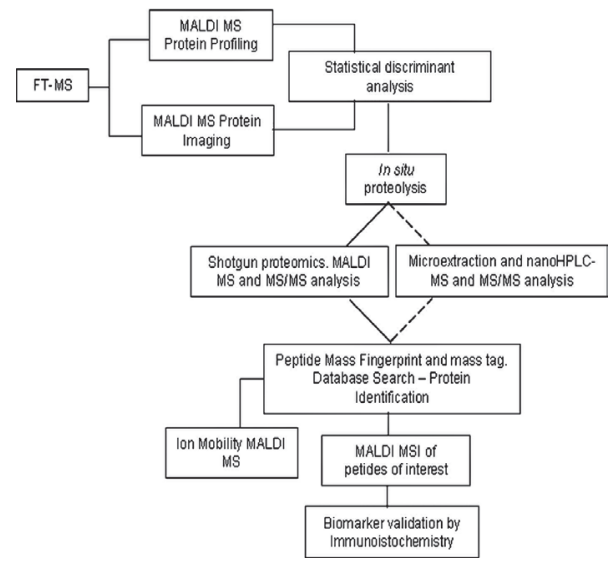

Figure 5 - Proposed MALDI MS based proteomic workflow for the analysis of intact tissue sections. Dashed lines indicate parallel non in situ analyses that can be performed. 